DOI: 10.17805/trudy.2015.6.4

\title{
Б. А. РУЧКИН КАК ИССЛЕДОВАТЕЛЬ ИСТОРИИ ВЕЛИКОЙ ОТЕЧЕСТВЕННОЙ ВОЙНЫ (ПАМЯТИ СТАРШЕГО ТОВАРИЩА)
}

\author{
О. Г. Жукова \\ (Московский гуманитарный университет)
}

Аннотация: Статья посвящена памяти историка молодежного движения, директора Центра исторических исследований Института фундаментальных и прикладных исследований Московского гуманитарного университета, Ученого секретаря ИФПИ МосГУ, доктора исторических наук, профессора, Почетного работника высшего профессионального образования Бориса Александровича Ручкина.

Ключевые слова: Б. А. Ручкин; Великая Отечественная война; Вторая мировая война; исторические исследования; мемуары; миф; фальсификация; учебник истории

\section{B. A. RUCHKIN AS A SCHOLAR OF HISTORY OF GREAT PATRIOTIC WAR (IN MEMORIAM OF A SENIOR COLLEAGUE)}

\author{
O. G. Zhukova \\ (Moscow University for the Humanities)
}

\begin{abstract}
The article is dedicated to the memory of the historian of the youth movement, Director of the Center for Historical Studies at the Institute of Fundamental and Applied Studies, Moscow University for the Humanities, Academic Secretary of the Institute of Fundamental and Applied Studies, Doctor of History, Professor, Honorary worker of higher professional education of the Russian Federation Boris A. Ruchkin.
\end{abstract}

Keywords: B.A. Ruchkin; Great Patriotic war; World War II; historical studies; memoirs; myth; falsification; history textbook

Безвременная кончина профессора Бориса Александровича Ручкина 2 июня 2015 г. стала поистине неожиданной, тяжелой и невосполнимой утратой для всей кафедры истории Московского гуманитарного университета. После случившегося последнее заседание кафедры, на котором присутствовал Борис Александрович, приобретало особый смысл. В мельчайших подробностях вспоминается коллегам тот день, тот непринужденный разговор, плавно перетекающий от кафедральных вопро- 
сов и проблем к исторической проблематике, интересной всем, потом - к обычным жизненным перипетиям и обратно. Вспоминается и Борис Александрович, его, как обычно, остроумные и ироничные замечания, внимательный взгляд карих глаз и едва заметная печать грусти на лице, когда он вдруг обмолвился о необходимости медицинского обследования. И снова - шутки, и снова интересные повороты в общем разговоре, на которые направлял профессор Ручкин, неожиданно задав дискуссионный вопрос.

Борис Александрович вызвал всеобщее оживление, спросив, насколько объективным историческим источником мы можем считать воспоминания очевидцев событий? Оказывается, сам он к тому моменту прочел 20 (!) мемуаров о Великой Отечественной войне наших крупнейших военачальников и собирался писать большую исследовательскую работу на основе этих документов. Говорил, что сравнительный анализ дает ему обширнейшую базу для размышлений, рассказывал, что необычайно интересно видеть разночтения или, наоборот, единомыслие полководцев в оценке тех или иных исторических событий.

Тогда я тоже поделилась с коллегами своим видением предложенной темы. На шутливой волне напомнила о сюжете сказа Павла Бажова «Огневушка-поскакушка». Он повествует о том, что иногда, во время вечерней трапезы уральских золотоискателей, усевшихся вокруг общего костра, из огня появлялась чудесная маленькая девочка - ОгневушкаПоскакушка. Кружила она перед их глазами в удивительном танце, а потом уходила под землю. Считалось, что в месте ее исчезновения можно найти богатую золотую жилу. Только вот каждый, сидящий у костра, был готов поклясться, что видел, где скрылась она, а место показывал не то, что другие. И начинался среди старателей спор, доходящий до драки. И, конечно же, обычно Огневушка показывалась только тогда, когда много людей собиралось у костра... Это ли не яркая и образная иллюстрация к вопросу об объективности не только мемуарных источников, но и любых свидетельских показаний, объясняющая и парадоксальность фраз: «Врет, как очевидец» и «У каждого своя правда»? Помню, мой рассказ развеселил Бориса Александровича, и им была брошена фраза типа: «Вечно ты, Жукова, придумаешь что-то такое...» Я знала, что из уст профессора Ручкина - это высокая похвала.

...И вот, буквально через несколько дней, трагическая новость - профессора Ручкина не стало. Ушел для всех совершенно неожиданно, полный творческих планов, и мы теперь уже никогда не прочтем его сравнительного анализа воспоминаний полководцев Великой Отечественной, а оно, при необычайной профессиональной скрупулезности Бориса Александровича, обещало быть интереснейшим, и, конечно, стало бы значи- 
тельным вкладом в историографию войны...

Но в его творческом наследии есть несколько работ, посвященных вопросам истории Второй мировой войны. Для него, историка молодежного движения и комсомола, эта тема была новой, и взялся он за нее, можно сказать, с «комсомольским задором», а отрабатывал «передовыми комсомольскими темпами» - здесь должен быть смайлик, думаю, Борис Александрович, как всегда, оценил бы мой юмор...

Нам выпала судьба в составе большого творческого коллектива ученых МосГУучаствовать в работе над проектом «Демифологизация истории России», поддержанным грантом Общества «Знание» России. В рамках этого исследования Б. А. Ручкиным была написана статья «1941 (Ручкин, 2014а). В ней автор представляет порой диаметрально противоположные взгляды современных исследователей на события лета и осени 1941 г., и, по сути, вскрывает механизм создания исторической фальсификации на цитатах неудавшегося разведчика В. Резуна (Суворова), забытого уже при жизни политика Г. Попова, историка-любителя с техническим образованием, автора книги со странноватым для исторической науки «медицинским» названием «Июнь 41-го. Окончательный диагноз» М. Солонина, специалиста по «Британской метаэтнической общности» Б. Соколова и др.

Причем, профессор Ручкин начинает свой анализ с напоминания цитаты автора книги «Вызываю дух Власова», экс-мэра Москвы Г. Попова, утверждавшего, что за 10 дней лета 1941 г. «наступил полный крах социализма»: «...народ - и, соответственно, армия - не хотели умирать за советский строй, за сталинский социализм, за диктатуру пролетариата» (цит. по: там же). Не иначе, как «дух Власова» на спиритическом сеансе нашептал Гавриилу Харитоновичу такой вывод!

Парадоксально, что в анализе Б. Ручкина в спор с забытым столичным мэром вступают не только современные исследователи - А. Мартиросян, Ю. Жуков, А. Вдовин, А. Бобров, В. Литвиненко, С. Кремлев и др., но и ... гитлеровские генералы!

По основному пункту «обвинения» отвечает Г. Попову адмирал Канарис в июле 1941 г.: «Не все идет по намеченному плану. Увеличиваются признаки того, что эта война не только не вызовет ожидавшийся в России внутренний коллапс, но, напротив, приведет к укреплению большевизма» (там же: 129).

И, как историк комсомола, вписавшего в историю войны множество героических страниц, Б. Ручкин резюмирует: «то, что народ и армия сражались за социализм, подтверждает следующая статистика: второе, военное, полугодие 1941 г. в Красной Армии было принято в члены партии 126625 чел. Против 27068 чел., принятых в первом, довоенном, полугодии. В целом в годы войны только в армии и на флоте в партию вступили 3788 тыс. чел.» (там же). 
Важнейшая особенность историософских выкладок любого историка - побудить своего читателя к дальнейшему размышлению над представленными фактами, вызвать желание продолжить его мысль, обогатить тему собственными примерами и сделать собственные выводы. Потому, продолжая мысль старшего товарища, отмечу, что среди многих мотивацией будущих победителей к вступлению в члены ВКП (б) была извечная черта нашего менталитета - идти наперекор врагу во всем. Всем было известно, что в плену и в оккупации фашисты именно коммунистов и комсомольцев уничтожают первыми и с особой жестокостью. Мой дед партизанский летчик Николай Иванович Жуков, кавалер орденов Ленина, Красного Знамени, Отечественной войны 1 степени и многих медалей, поменял комсомольский билет на партийный в суровом 1942 г. Он понимал, что теперь у него одна «привилегия» - первым пойти в бой и первым умереть. Прежде всего, - за Родину, а уж потом - и за советский строй, подаривший ему, деревенскому мальчишке, путевку в небо, и в такую жизнь, о которой и мечтать не могли его предки - ткачи из небольшой подмосковной деревеньки.

Только вот историку-любителю с техническим образованием М. Солонину, видимо, виднее, раз уверенно утверждает, что «в Красной Армии было мало мотивации для вооруженной борьбы». И даже считает, что «В самой краткой формулировке ответ на вопрос о причине поражения может быть сведен к трем словам: армия не воевала. На полях сражения 1941 г. встретились не две армии, организованные и работающие как отлаженный часовой механизм: вооруженные силы нацистской Германии с одной стороны, и огромная вооруженная толпа - с другой» (там же: 126).

Но что-то не так пошло в «этом отлаженном часовом механизме», если его будильник, до упора заведенный «часовщиком»-Гитлером, не «прозвенел» в нашей столице уже в августе-сентябре 1941 г., как планировалось, и, по сути, так и не прозвенел вовсе... Да ведь и «поражения», в котором уверяет нас М. Солонин, тоже не было. Разумеется, за исключением поражения германского «часового механизма», состоявшегося в Берлине в мае 1945 г.

Тому причиной «огромная вооруженная толпа» (по Солонину), о которой гитлеровский генерал Г. Блюментрит говорит совсем в иных, уважительных выражениях: «...первые сражения в июне 1941 г. показали нам, что такое Красная Армия. Наши потери достигли 50 \%. Пограничники защищали старую крепость в Брест-Литовске, сражаясь до последнего человека... Поведение русских войск даже в этой первой битве являло собой поразительный контраст с поведением поляков и западных союзников, когда те терпели поражение» (там же).

Картина острой полемики авторов из разных исторических «станов» 
и даже из разных стран и исторических эпох, нарисованная профессором Ручкиным, приводит к ясному видению: тезис «мифотворцев» от истории, «сведенный к трем словам»: «армия не воевала», можно так же разбить тремя словами - не надо врать! Или, ответим словами Б. А. Ручкина, более развернуто: «миф - «армия не воевала» - не состоятелен. Не было бы Брестской крепости, Гродно, обороны Смоленска, битвы под Ельней, Вермахт дошел бы до Москвы именно в августе 1941 г. Операция «Барбаросса» была сорвана» (там же).

Тема исторической объективности, бережного и уважительного отношения к отечественной истории была продолжена профессором Ручкиным в других его историософских статьях-размышлениях. Рассматривая общие и частные вопросы патриотизма в российском обществе, он снова возвращается к теме Великой Отечественной войны: «К патриотизму и в царской, и в Советской России обращалась власть, особенно в критические моменты для судеб страны. В царской России только ордена Св. Георгия были удостоены свыше 10, 5 тыс. человек, в СССР звания Героя Советского Союза - 12 776. В годы Великой Отечественной войны кавалерами разных степеней ордена Славы стали около миллиона человек. В военное время патриотизм осязаем, понятен каждому: всем народом встать на защиту Родины. Но что такое патриотизм в мирное время, и каково его содержание, отличающееся от патриотизма военного времени?» (Ручкин, 2015: 54).

Ответ историка, согласного с мнением Президента РФ на этот счет, - «требуется переопределение патриотизма», т. к. пришла пора «рассматривать патриотизм не как вспомогательное средство, мобилизующее народ на достижение неких высоких целей, а как суть всей российской политики» (там же).

Автор ссылается на слова Президента о том, что «оппозиционер, даже очень жесткий, он в конечном итоге до конца борется за интересы Родины». Но, увы, нынешние «западники» отнюдь не разделяют установки на своеобразный «прозападный», но все же, патриотизм своих предшественников второй половины XIX века. Б. А. Ручкин отмечает, что «время требует сплочения перед угрозами», а, рассматривая взгляды на будущее страны из «стана» оппозиции, с отсылкой на известное изречение Зиновьева, резюмирует: «метишь в Путина, а попадаешь в Россию» (там же: 55). И тут же автор говорит о «задачах, которые ставятся перед либеральным сообществом»: «Россия проявляет себя как член примитивного сообщества государств и является, по сути, феодальной. Рецепт борьбы с этим государством видится в том, чтобы привлечь жителей, учителей и родителей школьников к борьбе с героикой прошлого: надо создать параллельную историю, поскольку нынешняя - это лишь история войн и 
царствований, не несущая в себе ничего позитивного в либеральном понимании... Словом, надо забыть Невского, Суворова... Жукова, Космодемьянскую, Гагарина» (там же: 56). «Рецепт борьбы с этим государством» - ни больше, ни меньше!

«Одной из целей холодной войны является исковеркать нашу историю, растоптать ее духовные ценности» - предостерегает профессор Ручкин, и потому «идея, которой надлежит сплотить общество для достижения высоких целей, не может работать сама, в автоматическом режиме» (там же).

...На проблемы, так сказать, новейшей мифологии истории, приходящей на смену мифологии старой, указывал профессор Ручкин в статье «Новый учебник истории: новая мифология»: «Что же получается? Октябрьская революция изымается из процесса обучения, и, стало быть, из памяти подрастающего поколения. Социалистическая революция уравнивается с буржуазно-демократической, и тем самым скрывается качественное отличие Великого Октября от февраля 1917 г. Таких революций до российского Октября в мире не было. Сила его воздействия на общемировые процессы признана одним из важнейших событий XX в.» (Ручкин, 2014b: Электр. ресурс). Борис Александрович обращает внимание на прямо-таки исторический казус, сложившийся в современной нашей реальности: «Итак, Великий Октябрь отменен, а реконструкцию парада 1941 г. сохранили. В официальных российских календарях 7 ноября обозначили как «День воинской славы России - День проведения военного парада на Красной площади в 1941 году». Здесь уместно еще раз сказать: без Великого Октября не было бы и Великой Победы, разорванной оказывается преемственность поколений» (там же).

Добавим: разве можно Великую Победу рассматривать в отрыве от событий I мировой войны, двух революций 1917 г., послевоенного восстановления страны от разрухи и даже крушения СССР? Очевидно, что нельзя. И все чаще слышим мы рекомендации говорить не о Великой Отечественной войне, а о II мировой, как ее, мол, принято называть «во всем цивилизованном западном мире».

Значит, нас, историков, ждет впереди большая, трудная, но интереснейшая задача по созданию внятной исторической концепции, представленной с позиций патриотизма и в интересах нашего государства и по созданию новых учебников истории, о которых ныне ведется так много споров.

А творческое наследие, глубокие и своевременные мысли профессора Ручкина станут для нас заветом на долгие времена. 


\section{СПИСОК ЛИТЕРАТУРЫ}

Ручкин, Б. А. (2014а) 1941-й: миф «Армия не воевала» (историческое обозрение) // Знание. Понимание. Умение. № 2. С. 125-130.

Ручкин, Б. А. (2014b) Новый учебник истории: новая мифология [Электронный ресурс] // Информационный гуманитарный портал «Знание. Понимание. Умение». № 4. URL: http://www.zpu-journal.ru/ezpu/2014/4/Ruchkin_New-Textbook-History-Mythology/ (дата поступления: 20.08.2015).

Ручкин, Б. А. (2015) Российское общество: патриотизм XXI века // Знание. Понимание. Умение. № 1. С. 52-70.

Жукова Ольга Германовна - кандидат исторических наук, доцент кафедры истории МосГУ, член Союза писателей России и Союза журналистов Москвы. Адрес: 111395, Москва, ул. Юности, д. 5 . Тел.: + 7 (499) 374-5581. Эл. адрес: letchikova@mail.ru

Zhukova Olga Germanovna, Candidate of History, Associate Professor, Department of History, Moscow University for the Humanities; Member, Russian Union of Writers; Member, Moscow Union of Journalists. Postal address: 5 Yunosti St., 111395, Moscow, Russian Federation. Tel.: +7 (499) 374-55-81. E-mail: letchikova@mail.ru 